\title{
Systemic Resistance in Arabidopsis Induced by Rhizobacteria Requires Ethylene-Dependent Signaling at the Site of Application
}

\author{
Marga Knoester, ${ }^{1}$ Corné M. J. Pieterse, ${ }^{1}$ John F. Bol, ${ }^{2}$ and Leendert C. Van Loon ${ }^{1}$ \\ ${ }^{1}$ Institute of Biology, Section Phytopathology, Utrecht University, P.O. Box 80084, 3508 TB Utrecht, \\ The Netherlands; ${ }^{2}$ Institute of Molecular Plant Sciences, Gorlaeus Laboratories, Leiden University, \\ P.O. Box 9502, 2300 RA Leiden, The Netherlands \\ Accepted 23 April 1999.
}

\begin{abstract}
Root colonization of Arabidopsis thaliana by the nonpathogenic, rhizosphere-colonizing, biocontrol bacterium Pseudomonas fluorescens WCS417r has been shown to elicit induced systemic resistance (ISR) against Pseudomonas syringae pv. tomato (Pst). The ISR response differs from the pathogen-inducible systemic acquired resistance (SAR) response in that ISR is independent of salicylic acid and not associated with pathogenesis-related proteins. Several ethylene-response mutants were tested and showed essentially normal symptoms of Pst infection. ISR was abolished in the ethylene-insensitive mutant etr1-1, whereas SAR was unaffected. Similar results were obtained with the ethylene-insensitive mutants ein 2 through ein7, indicating that the expression of ISR requires the complete signal-transduction pathway of ethylene known so far. The induction of ISR by WCS417r was not accompanied by increased ethylene production in roots or leaves, nor by increases in the expression of the genes encoding the ethylene biosynthetic enzymes 1-aminocyclopropane-1carboxylic (ACC) synthase and ACC oxidase. The eir1 mutant, displaying ethylene insensitivity in the roots only, did not express ISR upon application of WCS417r to the roots, but did exhibit ISR when the inducing bacteria were infiltrated into the leaves. These results demonstrate that, for the induction of ISR, ethylene responsiveness is required at the site of application of inducing rhizobacteria.
\end{abstract}

Additional keywords: bacterial speck disease, ethylene response mutants.

Induced resistance is the phenomenon by which a plant, upon appropriate stimulation, acquires an enhanced level of resistance against a broad spectrum of pathogens. The classic

Corresponding author: L. C. Van Loon; Telephone: +31-30-2536862; Fax: +31-30-2518366; E-mail: L.C.Vanloon@Bio.uu.nl

Current address of Marga Knoester: DLO-Centre for Plant Breeding and Reproduction Research (CPRO-DLO), P.O. Box 16, 6700 AA Wageningen, The Netherlands.

This article is in the public domain and not copyrightable. It may be freely reprinted with customary crediting of the source. The American Phytopathological Society, 1999. way of obtaining induced resistance is achieved by infection with a necrotizing pathogen, upon which the plant becomes more resistant to subsequent pathogen attack, both locally and systemically. This type of induced resistance is called systemic acquired resistance (SAR) and was first characterized in tobacco infected with tobacco mosaic virus (TMV) (Ross 1961a, 1961b). Pathogen-induced SAR is accompanied by an early increase in salicylic acid (SA) (Malamy et al. 1990; Métraux et al. 1990). Accumulation of SA is essential for the development of SAR, since transgenic plants that are unable to accumulate SA have lost their ability to express SAR (Gaffney et al. 1993). Infection of a plant by a necrotizing pathogen is also accompanied by a burst of ethylene production (Ross and Williamson 1951; De Laat and Van Loon 1982; Mauch et al. 1984; Spanu and Boller 1989). The role of ethylene in SAR seems to be plant species dependent. In Arabidopsis, Lawton et al. (1995) showed that the ethylene-insensitive etrl-1 mutant is fully capable of mounting an SAR response. In contrast, in transgenic tobacco plants expressing the Arabidopsis mutant etrl-1 gene, a substantially reduced SAR response was observed (Knoester 1998). SAR is associated with the expression of the so-called SAR genes (Ward et al. 1991), including genes coding for pathogenesis-related proteins (PRs) (Van Loon 1985; Linthorst 1991), which are often used as markers for the induced state. Exogenous application of the chemicals SA, 2,6-dichloroisonicotinic acid (INA), or benzothiadiazole mimic pathogen-induced SAR by inducing the same set of SAR genes (Ward et al. 1991; Uknes et al. 1992; Friedrich et al. 1996; Görlach et al. 1996; Lawton et al. 1996).

Another type of induced resistance was reported in 1991, when selected strains of nonpathogenic, root-colonizing, plant growth-promoting rhizobacteria (PGPR) were shown to induce systemic resistance in carnation (Van Peer et al. 1991) and cucumber (Wei et al. 1991). To distinguish this enhanced defensive capacity from pathogen-induced SAR, the induced protection was termed rhizobacteria-mediated induced systemic resistance (ISR) (Pieterse et al. 1996; Van Loon 1997; Van Loon et al. 1998). Previous research on PGPR had demonstrated their capability to control soilborne pathogens by competition for nutrients, siderophore-mediated competition for iron, or antibiosis (Bakker et al. 1991; Schippers 1992; Thomashow and Weller 1996). ISR was found to constitute a novel mechanism by which these rhizobacteria can suppress 
plant diseases. Enhanced disease resistance is induced irrespective of whether the rhizobacteria are applied to the roots or the leaves (Hoffland et al. 1995; Pieterse et al. 1996).

Rhizobacteria-mediated ISR differs from pathogen-induced SAR in several ways. Contrary to the situation with SAR, ISR is not accompanied by the accumulation of PRs (Hoffland et al. 1995; Pieterse et al. 1996; Van Wees et al. 1997). Moreover, it was demonstrated by Pieterse et al. (1996) that in Arabidopsis ISR is independent of SA accumulation. When the ethylene response mutant etrl-1 was used, it was found that this mutant had lost the ability to be induced by rhizobacteria (Pieterse et al. 1998), whereas it was still capable of expressing SAR (Lawton et al. 1994; Pieterse et al. 1998). Thus, responsiveness to ethylene appears to be necessary for the induction of ISR. Conversely, treatment of Arabidopsis with the ethylene precursor 1-aminocyclopropane-1-carboxylic acid (ACC) induced resistance against Pseudomonas syringae pv. tomato (Pst), indicative of a role for ethylene in the ISR signal-transduction pathway.

Ethylene signaling has been studied extensively in Arabidopsis with mutants that are altered in the triple response phenotype of dark-grown seedlings in the presence of ethylene. Characteristics of the ethylene-induced triple response include the inhibition of root and hypocotyl elongation, radial swelling of the hypocotyl and root, and exaggeration of the curvature of the apical hook. Several mutants were isolated that either fail to respond to exogenous ethylene, or constitutively display the response in the absence of the hormone (Guzman and Ecker 1990). This resulted in the identification of several genes that constitute a signal-transduction pathway resembling the osmolarity response pathway in yeast (Ota and Varshavsky 1993; Maeda et al. 1994). The earliest steps in the pathway are defined by the ethylene receptor type ETR1, EIN4, ETR2, and ERS (Chang et al. 1993; Hua et al. 1997). Receptor mutants all display dominant ethylene insensitivity, indicating that they have similar or overlapping roles in ethylene perception and signal transduction. Downstream of the receptors is the ctrl gene, which is thought to be a negative regulator of the ethylene response, since the $c t r 1-1$ mutant shows complete activation of all known ethylene-induced phenotypes in the absence of ethylene (Kieber et al. 1993). CTR1 is followed by EIN2, which displays ethylene insensitivity when mutated. CTR1 is thought to negatively regulate EIN2, possibly via a MAP kinase cascade (Ecker 1995). The ein3 gene has been cloned, and characterized as coding for a positive regulator of ethylene responses, acting downstream of EIN2 (Chao et al. 1997). The positions of EIN5, EIN6, and EIN7 are not yet known.
However, they all appear to act downstream of CTR1. Additional mutations known to abolish (some) ethylene responses are less well characterized.

To elucidate which parts of the ethylene signal-transduction pathway are required for rhizobacteria-mediated ISR, we analyzed a set of these ethylene response mutants for their ability to express ISR. For comparison, the mutants were similarly analyzed for their potential to express pathogeninduced SAR.

\section{RESULTS}

\section{Disease development in ethylene mutants.}

To investigate the involvement of ethylene in induced resistance against Pst, it is important that symptoms of Pst infection in the ethylene mutants do not deviate from those of wild-type plants to any gross extent. Because ethylene plays a role in the regulation of leaf senescence, insensitivity to ethylene could interfere with the pathogen-induced accelerated aging resulting in chlorophyll loss and yellowing symptoms. The ethylene response mutants analyzed are listed in Table 1 . Mutant etr 1-1 plants have enhanced levels of chlorophyll compared with wild-type Col-0 (Bleecker et al. 1988), but after the plants were dipped in a solution containing $2.5 \times 10^{7} \mathrm{CFU}$ $\mathrm{ml}^{-1}$ of virulent Pst, typical symptoms of bacterial speck disease, consisting of extensive chlorosis progressing into spreading necrosis, were observed. For ein2-1, Bent et al. (1992) described that these plants showed only minimal symptoms after vacuum infiltration with $10^{5} \mathrm{CFU} \mathrm{m}{ }^{-1}$ of virulent Pst. In our experiments, ein2-1 developed clear symptoms after the plants were dipped into a suspension of $2.5 \times 10^{7} \mathrm{CFU} \mathrm{ml}{ }^{-1}$ of virulent Pst. Although the appearance of the symptoms was different from those on Col-0 in that leaves lacked the characteristic yellowing, clearly visible water-soaked lesions were apparent. The ein3-1 plants also showed water-soaked lesions, but less obvious than those on ein2-1 plants, with more yellowing. The other ethylene response mutants tested, except for ein6, axr1-12, and ctrl-1, showed extensive disease symptoms similar to Col-0 and etrl1 plants. Mutants ein6 and axr 1-12 hardly developed symptoms even after inoculation with $1.25 \times 10^{8} \mathrm{CFU} \mathrm{m}{ }^{-1}$ of virulent Pst.

Mutant ctr $1-1$ constitutively displays ethylene responses. In this mutant, Pst infection did not result in symptom formation. To analyze whether the lack of symptom formation was caused by an inability of Pst to enter and multiply in ctrl-1 leaves, the number of bacteria was determined immediately

Table 1. Ethylene mutants used in bioassays

\begin{tabular}{llll}
\hline Mutant & Phenotype & Ecotype & Reference \\
\hline etr1-1 & Ethylene insensitive, dominant & Col-0 & Bleecker et al. 1988 \\
ein2-1 & Ethylene insensitive, recessive & Col-0 & Guzman and Ecker 1990 \\
ein3-1 & Ethylene insensitive, recessive & Col-0 & Kieber et al. 1993 \\
ein4-1 & Ethylene insensitive, dominant & Col-0 & Roman et al. 1995 \\
ein5-1 & Ethylene insensitive, recessive & Col-0 & Roman et al. 1995 \\
ein6 & Ethylene insensitive, recessive & Ler & Roman et al. 1995 \\
ein7 & Ethylene insensitive, semidominant & Col-0 & Roman et al. 1995 \\
eto1-1 & Ethylene overproducer, recessive & Col-0 & Guzman and Ecker 1990 \\
eir1-1 & Ethylene insensitive root, recessive & Col-0 & Roman et al. 1995 \\
axr1-12 & Ethylene and auxin insensitive root, recessive & Col-0 & Estelle and Somerville 1987; Lincoln et al. 1990 \\
ctr1-1 & Constitutive triple response, recessive & Col-0 & Kieber et al. 1993 \\
\hline
\end{tabular}


after challenge inoculation by dipping and 4 days later. In wild-type Col-0, Pst increased from $1.75 \times 10^{5} \mathrm{CFU} \mathrm{g}^{-1}$ fresh weight $(t=0)$ to $1.2 \times 10^{7} \mathrm{CFU} \mathrm{g}^{-1}(t=4$ days). In ctrl-1, these values were $4.9 \times 10^{5}$ and $4.7 \times 10^{7} \mathrm{CFU} \mathrm{g}{ }^{-1}$, respectively, an increase of the same order of magnitude as in Col-0 plants, indicating that the lack of symptoms on ctrl-1 plants was not caused by reduced entry or growth of Pst in the leaves. In addition to the lack of symptoms, the extremely small phenotype of $c t r l-1$, due to its constitutive triple response, rendered this mutant unsuitable for further assays.

\section{Analysis of ISR and SAR in ethylene mutants.}

To investigate which parts of the ethylene signaltransduction pathway are required for induced resistance, the expression of ISR and SAR was tested in etr l-1, the ethyleneinsensitive ein mutants, and the ethylene overproducer etol-1.

For wild-type Col-0, induction of ISR by WCS417r resulted in between 20 and $30 \%$ fewer diseased leaves. Induction of SAR was more effective than that of ISR, resulting in a reduction of the proportion of diseased leaves by $50 \%$. None of the ethylene-insensitive mutants etr 1-1, ein2-1, ein3-1, ein4-1, ein5-1, and ein7 expressed ISR in response to treatment with WCS417r. In contrast, their SAR response was unimpaired, and as strong as observed in Col-0 plants (Fig. 1). Also, for ein6, in the Ler background, the capacity to express ISR was abolished, whereas SAR was maintained. The ethylene overproducer etol-1 developed symptoms to the same extent as wild-type Col-0. In spite of its constitutive ethylene production, it likewise did not show an ISR response, whereas the SAR response was normal.

As the induction of ISR is established by colonization of the rhizosphere, we analyzed whether the absence of ISR in the ethylene response mutants was due to an inability of WCS417r to colonize the roots of these mutants. In each bioassay, root colonization by WCS417r was determined for both wild-type and mutant plants. Root colonization of wild-type plants varied between $3 \times 10^{6}$ and $6 \times 10^{7} \mathrm{CFU} \mathrm{g}{ }^{-1}$ fresh weight. Root colonization of the ethylene mutants never showed a significant difference from that of wild-type plants (data not shown).

\section{Rhizobacteria-mediated ISR requires ethylene sensitivity at the site of application.}

eirl-1 and axrl-12 are two mutants that are insensitive to ethylene in the roots only. To investigate whether the inability of the ein mutants to express ISR results from an inability to react to ethylene in the root or in the shoot, the eirl-1 and axr1-12 mutants were tested by applying WCS417r either in the soil, at transplanting, or to the leaves, by pressure infiltration 3 days before challenge inoculation.

When WCS417r was applied to the roots, both mutants behaved like the ein mutants, in that no ISR was expressed, whereas SAR could be induced normally in these mutants (Fig. 2A). Upon challenge inoculation, control plants of the axrl-12 mutant showed a low percentage of diseased leaves, whereas eirl-1 control plants were as diseased as Col-0 controls. Therefore, further analyses were performed on eirl-1 mutants only.

To check ethylene responsiveness of the eirl-1 mutant in the leaves, the expression of the ethylene-responsive gene hel was analyzed upon treatment with a concentration range of $\mathrm{ACC}$, and compared with hel gene expression in Col-0, ein2-
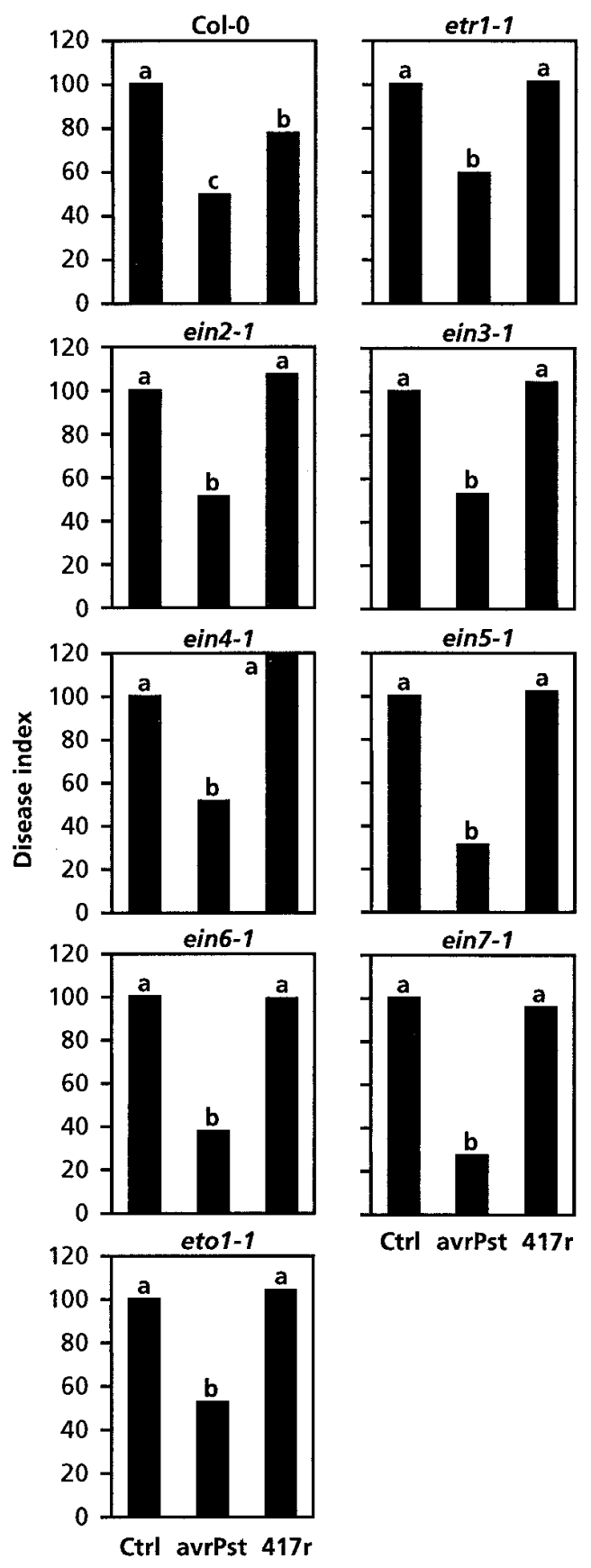

Fig. 1. Quantification of induced systemic resistance against Pseudomonas syringae pv. tomato infection in Col-0 and ethylene mutants grown in soil amended with $10 \mathrm{mM} \mathrm{MgSO}_{4}$ (Ctrl) or P. fluorescens WCS417r (417r), or pressure infiltrated in the leaves with the avirulent $P$. syringae pv. tomato (avrPst). Four days after challenge inoculation with virulent $P$. syringae pv. tomato, disease severity was scored by determining percent diseased leaves per plant. Disease index is the mean $(n=20)$ of percent of diseased leaves per plant relative to control treatment. Absolute values for percentages of diseased leaves in controls: Col-0 (52.3), etr1-1 (64.9), ein2-1 (62.5), ein3-1 (55.8), ein4-1 (58.5), ein5-1 (71.3), ein6 (31.1), ein7 (76.4), and eto11 (53.0). Within each frame, different letters indicate statistically significant differences between treatments by Fisher's least significant difference test $(\alpha=0.05)$. 
1, and etol-1 (Fig. 3). As expected, noninduced Col-O and eirl-1 plants showed a higher basal level of hel gene expression than ethylene-insensitive ein2-1. Expression was strongly increased upon application of ACC to Col-0 and eirl-1, but

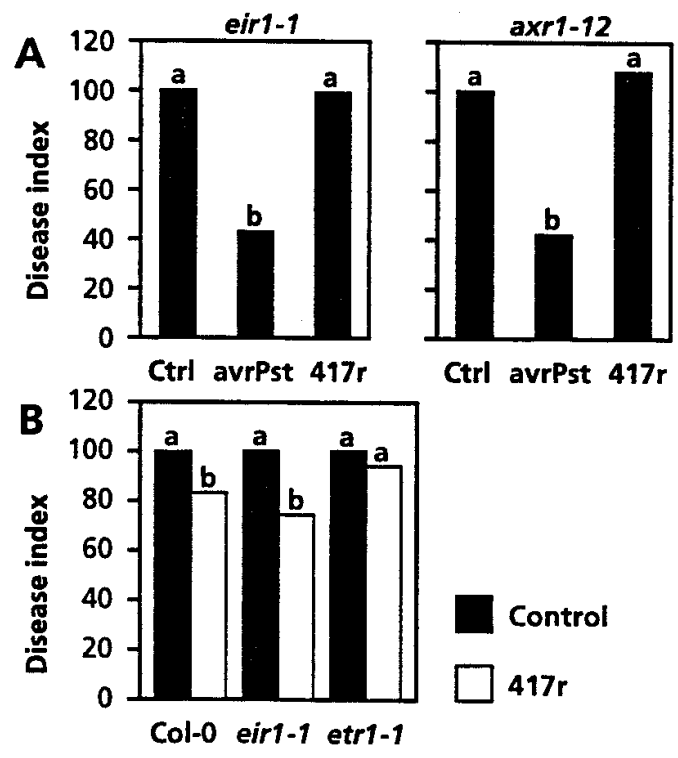

Fig. 2. A, Quantification of induced systemic resistance against Pseudomonas syringae pv. tomato infection in eirl-1 and axrl-12 plants grown in soil amended with $10 \mathrm{mM} \mathrm{MgSO}$ (Crtl) or P. fluorescens WCS417r (417r), or pressure infiltrated in the leaves with the avirulent pathogen P. syringae pv. tomato (avrRpt2) (avrPst). B, Quantification of induced systemic resistance against $P$. syringae pv. tomato infection in Col-O, eirl-1, and etrl-1 upon infiltration of three leaves per plant with either $10 \mathrm{mM} \mathrm{MgSO}{ }_{4}(\mathrm{Ctrl})$ or $10^{7} \mathrm{CFU} \mathrm{ml}^{-1}$ P. fluorescens WCS $417 \mathrm{r}$ (417r) 3 days before challenge inoculation. For bioassays shown in $\mathbf{A}$ and $\mathbf{B}, 4$ days after challenge inoculation with virulent $P$. syringae pv. tomato, disease severity was scored by determining percent diseased leaves per plant. Disease index is the mean $(n=20)$ of percent diseased leaves per plant relative to control treatment. Absolute values for percentages of diseased leaves in controls from eirl-1 and axrl-12: 56.6 and $24.8 \%$, respectively (A). In $\mathbf{B}$, absolute values for percentages of diseased leaves per plant in controls from Col-O, eirl-1, and etrl-1: $57.4,59.9$, and $64.4 \%$, respectively. Different letters indicate statistically significant differences between treatments by Fisher's least significant difference test $(\alpha=0.05)$. Experiments were performed twice with similar results. not in ein2-1, providing proof that eirl-1 leaves are similar to wild-type Col-0 leaves in sensitivity to ethylene. Ethyleneoverproducing etol-1 plants showed an elevated background level of hel gene expression, which was not further increased upon application of ACC.

Figure 2B shows the percentage of diseased leaves in WCS417r-treated plants relative to control plants when ISR was induced by infiltrating the rhizobacteria into the leaf. The level of resistance induced by leaf infiltration was somewhat less than that resulting from application of the bacteria to the roots. Nevertheless, Col-0 treated with WCS417r showed a significant reduction in the percentage of diseased leaves of $20 \%$, compared with noninduced control plants. The eirl-1 mutant likewise showed a reduction of as much as $25 \%$, whereas no significant ISR was seen in the ethyleneinsensitive etr $1-1$ plants. While the eirl-1 mutant did not develop ISR upon application of WCS417r to its roots, it expressed ISR at least as well as wild-type Col-0 when the bacterium was infiltrated in the ethylene-responsive leaves. The ISR response was not induced in ethylene-insensitive leaves of etr1-1. These results clearly demonstrate that, for ISR to develop, ethylene-dependent signaling is required at the site of application of the ISR-inducing bacteria.

\section{P. fluorescens WCS417r does not induce ethylene biosynthesis in Col-0.}

For ISR expression, ethylene has to act at the site of application of ISR-inducing bacteria. Moreover, our results with the ethylene-insensitive mutants demonstrate that the ISR response requires all known components of the ethylenesignaling pathway. It was shown recently that ACC induces a resistance against Pst infection similar to WCS417r-mediated ISR (Pieterse et al. 1998). The similarities in ACC-induced resistance and WCS417r-mediated ISR raised the question whether application of WCS417r to the roots results in locally elevated ethylene levels. Such increased ethylene levels could be instrumental in the generation of the systemic signaling compound that renders the plant more resistant to challenging pathogens. Further questions are whether expression of ISR also requires ethylene and whether, upon application of WCS417r to the roots, leaf ethylene levels are also elevated.

Ethylene measurements were performed on roots of Col-0 plants potted in soil with or without WCS417r. Results of a

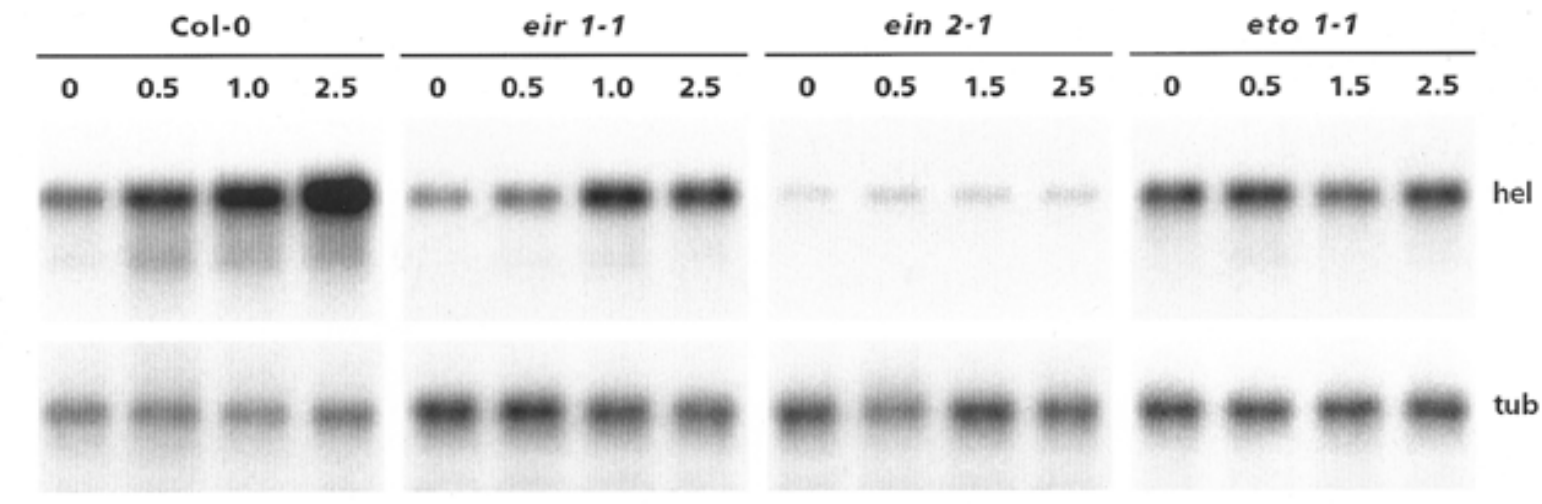

Fig. 3. Analysis of hel gene expression in leaves of Col-0, eir1-1, ein2-1, and eto1-1 plants. hel gene expression was analyzed 2 days after treatment with either $0.01 \%$ Silwet L-77 (0), or 0.5, 1, and $2.5 \mathrm{mM}$ ACC (1-aminocyclopropane-1-carboxylic acid) + 0.01\% Silwet L-77. To check for equal loadings, blot was stripped and hybridized with a proble for $\beta$-tubulin (tub). 
typical experiment are shown in Table 2. During the period of 3 weeks between transplant of the seedlings in bacterized soil and challenge inoculation, when bacteria were present on the roots at levels triggering ISR, a statistically significant difference in ethylene levels of roots from control and WCS417rtreated plants was never found. Leaves were analyzed similarly but, likewise, no statistically significant differences in ethylene production were observed between control and WCS417r-treated plants.

To examine the possibility that bacterization of roots is accompanied by an early, transient increase in ethylene production, expression of the ethylene biosynthetic genes ACCsynthase (acs) and ACC-oxidase (aco) was analyzed in the first week after seedling roots were exposed to the rhizobacteria. The acs gene family of Arabidopsis consists of five members, of which acs3 is a pseudogene of acs1 (Liang et al. 1992). acs $1, a c s 4$, and acs 5 were tested but showed no expression in roots at the level of detection. In contrast, acs 2 was clearly expressed (Fig. 4). However, acs 2 revealed similar expression patterns for control and WCS417r-treated roots. For both treatments, expression of acs 2 increased between 1 and 3 days after application of the bacteria and remained elevated, or occasionally declined by 7 days. aco gene expression showed a largely similar pattern with no apparent differences between control and WCS417r-treated roots. Thus, no signifi-

Table 2. Ethylene production (pmol g-1 $\mathrm{h}^{-1}$ ) for roots and leaves of Col0 control plants (Ctrl) or WCS417r-treated plants, 1, 2, or 3 weeks after potting $^{z}$

\begin{tabular}{lccccc}
\hline \multirow{2}{*}{$\begin{array}{l}\text { Time } \\
\text { (weeks) }\end{array}$} & \multicolumn{2}{c}{ Root } & & \multicolumn{2}{c}{ Leaf } \\
\cline { 2 - 3 } \cline { 5 - 6 } \cline { 5 - 6 } & Ctrl & WCS417r & Ctrl & WCS417r \\
\hline 1 & $138 \pm 38 \mathrm{a}$ & $129 \pm 23 \mathrm{abc}$ & & $136 \pm 41 \mathrm{c}$ & $102 \pm 39 \mathrm{~cd}$ \\
3 & $103 \pm 29 \mathrm{~cd}$ & $122 \pm 30 \mathrm{abc}$ & & $175 \pm 20 \mathrm{ab}$ & $184 \pm 15 \mathrm{a}$ \\
3 & $75 \pm 9 \mathrm{de}$ & $66 \pm 7 \mathrm{e}$ & & $144 \pm 10 \mathrm{c}$ & $155 \pm 16 \mathrm{bc}$ \\
\hline
\end{tabular}

${ }^{\mathrm{z}}$ Different letters indicate statistically significant differences between treatments by Fisher's least significant difference test $(\alpha=0.05)$. Experiments were performed three times with similar results.

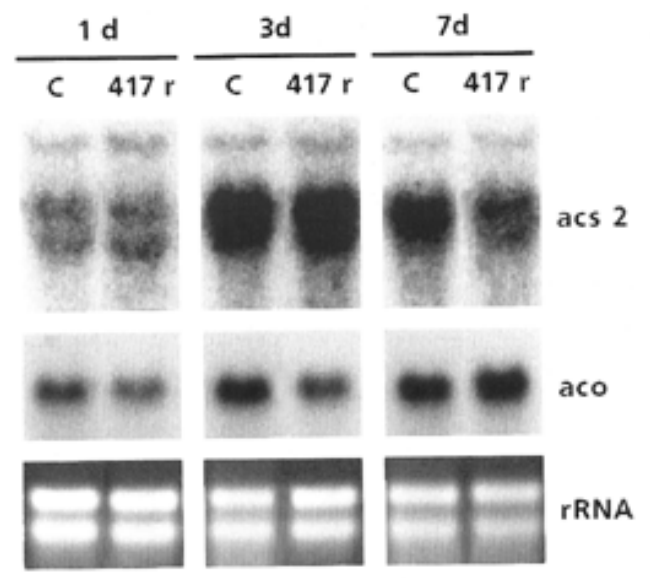

Fig. 4. Analysis of acs 2 and aco gene expression in roots of Col-0 plants. On rock-wool cubes, Col-0 roots were treated with either $10 \mathrm{mM}$ $\mathrm{MgSO}_{4}$ mixed with talcum powder as a carrier (C), or with Pseudomonas fluorescens WCS417 $\mathrm{r}$ applied in the same manner (417r). acs 2 and aco gene expression were analyzed 1,3, and 7 days after treatment, compared with patterns of rRNA stained with ethidium bromide. cant alterations in the expression of ethylene biosynthetic genes occurred associated with the induction of ISR.

\section{DISCUSSION}

ISR is the mechanism by which $P$. fluorescens WCS417r has been shown to reduce disease caused by Pst in Arabidopsis (Pieterse et al. 1996, 1998; Van Wees et al. 1997). The pathway by which ISR is induced is poorly understood. Clear differences were observed when ISR was compared with the well-established SAR response, in which SA accumulation and induction of $P R$ gene expression are associated with the resistance response. Neither occurs during the development of ISR and markers for the ISR response are not yet identified. However, responsiveness to both jasmonic acid (JA) and ethylene is necessary for the expression of ISR, and application of either methyl jasmonate (MeJA) or ACC induces a resistance in Arabidopsis similar to ISR (Pieterse et al. 1998). Application of MeJA to etrl-1 plants did not result in protection. However, treatment of the JA-nonresponsive mutant jarl with ACC did induce resistance, indicating that JA and ethylene responsiveness are successively engaged in signal transduction. Both SAR and ISR are dependent on NPR1, suggesting that at least some of the later steps leading to the resistant state are shared by the two types of induced resistance (Pieterse et al. 1998).

We have attempted to gain further insight into the pathway leading to ISR by performing a more extended analysis of the involvement of the ethylene signal-transduction pathway in the expression of ISR. Several steps in the ethylene signaltransduction pathway have been identified (Ecker 1995). The ethylene response mutants etr1-1, ein2-1, ein3-1, ein4-1, ein51, ein6, and ein7 were tested for the WCS417r-mediated ISR response and the pathogen-induced SAR response. WCS417rmediated ISR was abolished in all mutants tested, whereas all mutants were able to express pathogen-induced SAR. These observations support earlier findings by Lawton et al. (1994, 1995) that in Arabidopsis induction of SAR is ethylene independent. In contrast, ISR requires an intact ethylene response and, although the exact locations of EIN5, EIN6, and EIN7 in the ethylene signal-transduction pathway are not known, this indicates that all known ein genes in the pathway are required for the expression of ISR.

Because the ethylene signal-transduction pathway is necessary for full expression of the ISR response, the involvement of ethylene in the induction of ISR was further investigated. Bioassays with the eirl-1 mutant, displaying ethylene insensitivity in the roots only, shed additional light on the pathway by which ISR is induced. In this mutant, application of WCS417r to the roots did not result in an ISR response in the leaves. In contrast, infiltration of bacteria into the leaves did result in an ISR response. The eirl-1 leaves are normally sensitive to ethylene, in contrast to etrl-1 and ein mutants, which display complete ethylene insensitivity. This demonstrates that ethylene-dependent signaling is required at the site of application of inducing bacteria, be it roots or leaves, to obtain a full ISR response.

Whether ethylene sensitivity is required also at the site where the resistance is expressed cannot be assessed at present. However, this seems unlikely, because SAR can be expressed in ethylene-insensitive Arabidopsis. Thus, expression 
of resistance upon challenge inoculation is not impaired when ethylene cannot be perceived. The ethylene-overproducing mutant eto1-1 constitutively displays high levels of ethylene, but did not express enhanced resistance. Because hel gene transcript accumulation was not increased in response to ACC in the etol-1 mutant, it appears that the ethylene signaling pathway was somehow saturated and that application of ISRinducing bacteria did not provide additional stimuli for the induction of ISR.

Application of ISR-inducing WCS417r did not alter ethylene production or gene expression of ethylene biosynthetic genes in roots or leaves. Thus, there are no indications that WCS417r induced ISR in Arabidopsis by inducing ethylene biosynthetic genes or ethylene production. Some Pseudomonas spp. are capable of producing ethylene (Weingart and Völksch 1997), and it might be envisaged that not the plant, but WCS417r itself is producing the ethylene by which the ethylene signal transduction in the plant is activated. No conclusive evidence about ethylene production by WCS417r has been obtained so far (P. A. H. M. Bakker, personal communication). However, the ethylene-responsive genes hel (Potter et al. 1993) and pdf1.2 (Penninckx et al. 1996) are not induced in roots bacterized with WCS417r, making it unlikely that WCS417r produces biologically active amounts of ethylene (Pieterse et al. 1998).

Thus, induction of ISR requires all known components of the ethylene signaling pathway in the absence of an increase in ethylene production. This situation resembles the compatible interaction of rice with the rice blast fungus Magnaporthe grisea (Hebert) Barr., in which JA-inducible genes are activated without a concomitant increase in endogenous JA (Schweizer et al. 1997). In the JA-promoted senescence of detached rice leaves, ethylene is the hormone responsible for chlorophyll loss. However, ethylene levels decreased rather than increased, but apparently JA increased the sensitivity to ethylene (Tsai et al. 1996). Because induction of ISR by WCS417r is similarly dependent on both JA and ethylene, but no increase in ethylene production is apparent, it may also be envisaged that JA increases sensitivity to ethylene. JA appears to act before ethylene in the ISR signaling pathway (Pieterse et al. 1998). Whether application of ISR-eliciting rhizobacteria increases JA levels in the plant remains to be determined. However, it can be concluded that for expression of ISR in Arabidopsis, ethylene-dependent signaling is required at the site of application of inducing rhizobacteria, and that induction of ISR is not accompanied by elevated ethylene levels in the plant.

\section{MATERIALS AND METHODS}

\section{Bacterial cultures.}

A rifampicin-resistant mutant of the bacterial biocontrol strain Pseudomonas fluorescens WCS417 (WCS417r), effective in inducing systemic resistance in carnation (Van Peer et al. 1991), radish (Hoffland et al. 1995), and Arabidopsis (Pieterse et al. 1996), was used as the inducing rhizobacterium. WCS417r was grown on King's medium B (KB) agar plates (King et al. 1954) for $24 \mathrm{~h}$ at $28^{\circ} \mathrm{C}$. Bacteria were collected and resuspended in $10 \mathrm{mM} \mathrm{MgSO}_{4}$. The virulent bacterial leaf pathogen Pseudomonas syringae pv. tomato (Pst) DC3000 (Whalen et al. 1991) was grown overnight at $28^{\circ} \mathrm{C}$ in liquid $\mathrm{KB}$. The cells were collected by centrifugation and resuspended in $10 \mathrm{mM} \mathrm{MgSO}_{4}$. Its avirulent derivative DC3000 (avrRpt2), carrying plasmid pLAFR3 containing the avirulence gene $a v r$ Rpt2 (Whalen et al. 1991), was similarly cultured in liquid $\mathrm{KB}$ without $\mathrm{MgSO}_{4}$, supplemented with tetracycline $(40 \mu \mathrm{g} / \mathrm{ml})$.

\section{Cultivation of plants.}

Seeds of Arabidopsis thaliana ecotypes Columbia (Col-0) and Landsberg erecta (Ler) and their mutants were sown in sand. Seedlings were cultivated in a growth chamber with a 9h light $\left(200 \mu \mathrm{E} \mathrm{s}^{-1} \mathrm{~m}^{-2}\right.$ at $\left.24^{\circ} \mathrm{C}\right)$ and 15 -h dark period $\left(20^{\circ} \mathrm{C}\right)$ at $70 \%$ relative humidity. Ten- to 14 -day-old plants were transplanted individually in $60-\mathrm{ml}$ pots containing a 12:5 ( $\mathrm{vol} / \mathrm{vol}$ ) potting soil/sand mixture, autoclaved twice for $1 \mathrm{~h}$, and supplemented with either $10 \mathrm{mM} \mathrm{MgSO}_{4}$ or a suspension of WCS417r in $10 \mathrm{mM} \mathrm{MgSO}$, as described for the ISR bioassay.

Plants were watered regularly and supplied once a week with half-strength Hoagland solution $\left(2 \mathrm{mM} \mathrm{KNO}_{3}, 5 \mathrm{mM}\right.$ $\mathrm{Ca}\left[\mathrm{NO}_{3}\right]_{2}, 1 \mathrm{mM} \mathrm{KH} \mathrm{PO}_{4}, 1 \mathrm{mM} \mathrm{MgSO}$, and trace elements, $\mathrm{pH}$ 7) (Hoagland and Arnon 1938), containing $10 \mu \mathrm{M}$ Sequestreen (Fe-ethylenediamine-di[o-hydroxyphenylacetic acid]; CIBA-Geigy, Basel, Switzerland).

\section{ISR and SAR induction.}

Plants for the ISR and SAR bioassays were randomized. For each treatment, 20 plants were used. For induction of ISR through colonization of the roots, seedlings germinated on sand were transplanted in the potting soil/sand mixture supplemented with either $50 \mathrm{ml}$ of $10 \mathrm{mM} \mathrm{MgSO}_{4}$ containing $10^{9} \mathrm{CFU} \mathrm{ml^{-1 }} \mathrm{WCS} 417 \mathrm{r}$ per $\mathrm{kg}$ of soil, or an equal

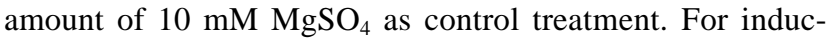
tion of ISR through leaf infiltration, 5-week-old plants were used. One day before treatment, plants were placed at $100 \%$ relative humidity. Three lower leaves per plant were infiltrated with a solution containing $10^{7} \mathrm{CFU} \mathrm{ml^{-1 }}$ of WCS417r, using a syringe without needle (Swanson et al. 1988). For induction of SAR the procedure used for the induction of ISR was followed, with $10^{7} \mathrm{CFU} \mathrm{ml^{-1 }}$ of avirulent Pst (avrRpt2).

\section{Challenge inoculation and disease assessment.}

Plants were subjected to challenge inoculation 3 weeks after transplanting in rhizobacteria-containing soil mixture or 3 days after leaf infiltration with avirulent Pst. One day before challenge, relative humidity was raised to $100 \%$, and kept at $100 \%$ during inoculation. Challenge inoculation was performed by dipping the leaves in a suspension of $2.5 \times 10^{7}$ $\mathrm{CFU} \mathrm{ml}{ }^{-1}$ of virulent Pst in $10 \mathrm{mM} \mathrm{MgSO}_{4}$, supplemented with $0.01 \%$ of the surfactant Silwet L-77. Four days later the proportion of diseased leaves per plant was determined (Pieterse et al. 1996, 1998). The number of Pst bacteria in inoculated leaves was determined in three sets of 20 randomly selected leaves per treatment. Leaves were weighed, rinsed thoroughly in sterile water, and homogenized in $10 \mathrm{mM}$ $\mathrm{MgSO}_{4}$. Subsequently, appropriate dilutions were plated onto $\mathrm{KB}$ agar supplemented with $50 \mathrm{mg} \mathrm{liter}^{-1}$ rifampicin and 100 $\mathrm{mg}$ liter $^{-1}$ cycloheximide. After $48 \mathrm{~h}$ of incubation at $28^{\circ} \mathrm{C}$, the number of rifampicin-resistant $\mathrm{CFU} \mathrm{\textrm {g } ^ { - 1 }}$ infected leaf tissue was determined. 
Data were statistically analyzed with analysis of variance followed by Fisher's test for least significant differences at $\alpha$ $=0.05$.

\section{Rhizosphere colonization.}

Roots ( 0.5 to $1.0 \mathrm{~g}$ fresh weight) from three to four plants were harvested in duplicate, and shaken vigorously for $30 \mathrm{~s}$ in $10 \mathrm{mM} \mathrm{MgSO}$ (10 ml per $1 \mathrm{~g}$ of roots), containing $0.5 \mathrm{~g}$ of glass beads $(0.17 \mathrm{~mm})$. Serial dilutions were plated on KB agar supplemented with cycloheximide (100 mg liter $\left.{ }^{-1}\right)$, ampicillin (50 mg liter ${ }^{-1}$ ), chloramphenicol (13 mg liter $\left.{ }^{-1}\right)$, and rifampicin (150 mg liter ${ }^{-1}$, which is selective for rifampicinresistant, fluorescent Pseudomonas spp. (Geels and Schippers 1983). After 2 days of incubation at $28^{\circ} \mathrm{C}$, the number of rifampicin-resistant $\mathrm{CFU} \mathrm{g}{ }^{-1}$ root fresh weight was determined.

\section{Ethylene determination.}

One, 2, and 3 weeks after potting of the plants, roots and leaves were harvested and enclosed in $30-\mathrm{ml}$ vials $(n=10)$. After incubation for 3 days under growth chamber conditions, the accumulated ethylene was measured by gas chromatography as described previously (De Laat and Van Loon 1983).

\section{RNA analysis.}

To study the expression of the ethylene-inducible hel gene, 5 -week-old plants were dipped in a solution containing various concentrations of ACC, $0.01 \%$ Silwet L-77, or $0.01 \%$ Silwet L-77 as control. Two days after treatment, leaf material was harvested, frozen in liquid nitrogen, and stored at $-80^{\circ} \mathrm{C}$ until RNA was isolated.

A time course experiment to analyze ISR-related acs and aco gene expression in seedling roots was performed by placing 2-week-old Col-0 seedlings horizontally on rock wool cubes drenched in half-strength Hoagland solution (Pieterse et al. 1996). A suspension of $5 \times 10^{8} \mathrm{CFU} \mathrm{ml}{ }^{-1} \mathrm{WCS} 417 \mathrm{r}$ in 10 $\mathrm{mM} \mathrm{MgSO}_{4}$, or $10 \mathrm{mM} \mathrm{MgSO}_{4}$ alone, was mixed 1:1 (vol/wt) with talcum powder and applied to the roots, which were then covered with rock wool cubes. At 1, 3, and 7 days after treatment, roots were harvested and talcum mix was removed by washing the roots in water. After drying, the roots were frozen in liquid nitrogen and stored at $-80^{\circ} \mathrm{C}$ for RNA isolation.

RNA was isolated as described previously (Linthorst et al. 1993). Total RNA $(20 \mu \mathrm{g})$ was separated on a $1 \%$ agarose gel in $15 \mathrm{mM}$ sodium phosphate $\mathrm{pH}$ 6.5, and transferred to Hybond $\mathrm{N}^{+}$filters (Amersham, 's-Hertogenbosch, The Netherlands). Hybridization was performed at $65^{\circ} \mathrm{C}$ in $250 \mathrm{mM}$ sodium phosphate $\mathrm{pH}$ 7.0, $1 \mathrm{mM}$ EDTA, 7\% sodium dodecyl sulfate, $1 \%$ bovine serum albumin, with randomly labeled probes of acs 1, -2, -4, and -5 (Liang et al. 1992), aco (GómezLim et al. 1993), and hel. The template for the hel probe was prepared by polymerase chain reaction with primers based on the published cDNA sequence (Potter et al. 1993).

\section{ACKNOWLEDGMENTS}

We thank the Arabidopsis Biological Resource Center (Columbus, $\mathrm{OH})$ for providing seeds of the ethylene mutants. A. Theologis is acknowledged for providing the Arabidopsis acs $1,-2,-4$, and -5 cDNAs and M. A. Gómez-Lim for the aco clone. We are further indebted to Hans van Pelt for expert technical assistance. This investigation was supported by the Life Sciences Foundation (SLW), which is subsidized by the Netherlands Organization for Scientific Research (NWO).

\section{LITERATURE CITED}

Bakker, P. A. H. M., Van Peer, R., and Schippers, B. 1991. Suppression of soil-borne plant pathogens by fluorescent pseudomonads: Mechanisms and prospects. Pages 217-230 in: Biotic Interactions and Soilborne Diseases. A. B. R. Beemster, G. J. Bollen, M. Gerlagh, M. A. Ruissen, B. Schippers, and A. Tempel, eds. Elsevier, Amsterdam.

Bent, A. F., Innes, R. W., Ecker, J. R., and Staskawicz, B. J. 1992. Disease development in ethylene-insensitive Arabidopsis thaliana infected with virulent and avirulent Pseudomonas and Xanthomonas pathogens. Mol. Plant-Microbe Interact. 5:372-378.

Bleecker, A. B., Estelle, M. A., Somerville, C., and Kende, H. 1988. Insensitivity to ethylene conferred by a dominant mutation in Arabidopsis thaliana. Science 241:1086-1089.

Chang, C., Kwok, S. F., Bleecker, A. B., and Meyerowitz, E. M. 1993. Arabidopsis ethylene response gene ETR1: Similarity of product to two-component regulators. Science 262:539-544.

Chao, Q., Rothenberg, M., Solano, R., Roman, G., Terzaghi, W., and Ecker, J. R. 1997. Activation of the ethylene gas response pathway in Arabidopsis by the nuclear protein Ethylene-insensitive 3 and related proteins. Cell 89:1133-1144.

De Laat, A. M. M., and Van Loon, L. C. 1982. Regulation of ethylene biosynthesis in virus-infected tobacco leaves. II. Time course of levels of intermediates and in vivo conversion rates. Plant Physiol. 69:240245.

De Laat, A. M. M., and Van Loon, L. C. 1983. The relationship between stimulated ethylene production and symptom expression in virusinfected tobacco leaves. Physiol. Plant Pathol. 22:261-273.

Ecker, J. R. 1995. The ethylene signal transduction pathway in plants. Science 268:667-675.

Estelle, M. A., and Somerville, C. R. 1987. Auxin-resistant mutants of Arabidopsis with an altered morphology. Mol. Gen. Genet. 206:200206.

Friedrich, L., Lawton, K., Dincher, S., Winter, A., Staub, T., Uknes, S., Kessmann, H., and Ryals, J. 1996. Benzothiadiazole induces systemic acquired resistance in tobacco. Plant J. 10:61-70.

Gaffney, T., Friedrich, L., Vernooij, B., Negrotto, D., Nye, G., Uknes, S., Ward, E., Kessmann, H., and Ryals, J. 1993. Requirement of salicylic acid for the induction of systemic acquired resistance. Science 261: 754-756.

Geels, F. P., and Schippers, B. 1983. Selection of antagonistic fluorescent Pseudomonas spp. and their root colonization and persistence following treatment of seed potatoes. Phytopathol. Z. 108:193-206.

Gómez-Lim, M. A., Valdés-López, V., Cruz-Hernandez, A., and Saucedo-Arias, L. J. 1993. Isolation and characterization of a gene involved in ethylene biosynthesis from Arabidopsis thaliana. Gene 134: 217-221.

Görlach, J., Volrath, S., Knauf-Beiter, G., Hengy, G., Beckhove, U., Kogel, K.-H., Oostendorp, M., Staub, T., Ward, E., Kessmann, H., and Ryals, J. 1996. Benzothiadiazole, a novel class of inducers of systemic acquired resistance, activates gene expression and disease resistance in wheat. Plant Cell 8:629-643.

Guzman, P., and Ecker, J. R. 1990. Exploiting the triple response of Arabidopsis to identify ethylene-related mutants. Plant Cell 2:513523.

Hoagland, D. R., and Arnon, D. I. 1938. The water culture method for growing plants without soil. Agric. Calif. Exp. Stn. Bull. 347:36-39.

Hoffland, E., Pieterse, C. M. J., Bik., L., and Van Pelt, J. A. 1995. Induced systemic resistance in radish is not associated with accumulation of pathogenesis-related proteins. Physiol. Mol. Plant Pathol. 46:309-320.

Hua, J., Sakai, H., and Meyerowitz, E. M. 1997. The ethylene receptor gene family in Arabidopsis. Pages 71-76 in: Biology and Biotechnology of the Plant Hormone Ethylene. A. K. Kanellis, C. Chang, H. Kende, and D. Grierson, eds. Kluwer, Dordrecht, The Netherlands.

Kieber, J. J., Rothenberg, M., Roman, G., Feldmann, K. A., and Ecker, J. 1993. CTR1, a negative regulator of the ethylene response pathway in Arabidopsis, encodes a member of the RAF family of protein kinases. Cell 72:427-441.

King, E. O., Ward, M. K., and Raney, D. E. 1954. Two simple media for the demonstration of phycocyanin and fluorescein. J. Lab. Clin. Med. 44:301-307.

Knoester, M. 1998. The involvement of ethylene in plant disease resistance. Ph.D. thesis. Utrecht University, Utrecht, The Netherlands. 
Lawton, K. A., Potter, S. L., Uknes, S., and Ryals, J. 1994. Acquired resistance signal transduction in Arabidopsis is ethylene dependent. Plant Cell 6:581-588.

Lawton, K., Weymann, K., Friedrich, L., Vernooij, B., Ukness, S., and Ryals, J. 1995. Systemic acquired resistance in Arabidopsis requires salicylic acid but not ethylene. Mol. Plant-Microbe Interact. 8:863870.

Lawton, K. A., Friedrich, L., Hunt, M., Weymann, K., Staub, T., Kessmann, H., and Ryals, J. 1996. Benzothiadiazole induces disease resistance in Arabidopsis by activation of the systemic acquired resistance signal transduction pathway. Plant J. 10:71-82.

Liang, X., Abel, S., Keller, J. A., Hen, N. F., and Theologis, A. 1992. The 1-aminocyclopropane-1-carboxylate synthase gene family of Arabidopsis thaliana. Proc. Natl. Acad. Sci. USA 89:11046-11050.

Lincoln, C., Britton, J. H., and Estelle, M. 1990. Growth and development of the axrl mutants of Arabidopsis. Plant Cell 2:1071-1080.

Linthorst, H. J. M. 1991. Pathogenesis-related proteins of plants. Crit. Rev. Plant Sci. 10:123-150.

Linthorst, H. J. M., Brederode, F. T., Van der Does, C., and Bol, J. F. 1993. Tobacco proteinase inhibitor-I genes are locally, but not systemically induced by stress. Plant Mol. Biol. 21:985-992.

Maeda, T., Wurgler-Murphy, S. M., and Saito, H. 1994. A twocomponent system that regulates an osmosensing MAP kinase cascade in yeast. Nature 369:242-245.

Malamy, J., Carr, J. P., Klessig, D. F., and Raskin, I. 1990. Salicylic acid: A likely endogenous signal in the resistance response of tobacco to viral infection. Science 250:1002-1004.

Mauch, F., Hadwinger, L. A., and Boller, T. 1984. Ethylene: Symptom, not signal for the induction of chitinase and $\beta$-1,3-glucanase in pea pods by pathogens and elicitor. Plant Physiol. 76:607-611.

Métraux, J.-P., Signer, H., Ryals, J., Ward, E., Wyss-Benz, M., Gaudin, J., Raschdorf, K., Schmid, E., Blum, W., and Inverardi, B. 1990. Increase in salicylic acid at the onset of systemic acquired resistance in cucumber. Science 250:1004-1006.

Ota, I. M., and Varshavsky, A. 1993. A yeast protein similar to bacterial two-component regulators. Science 262:566-569.

Penninckx, I. A. M. A., Eggermont, K., Terras, F. R. G., Thomma, B. P. H. J., De Samblanx, G. W., Buchala, A., Métraux, J.-P., Manners, J. M., and Broekaert, W. F. 1996. Pathogen-induced systemic activation of a plant defensin gene in Arabidopsis follows a salicylic acidindependent pathway. Plant Cell 8:2309-2323.

Pieterse, C. M. J., Van Wees, S. C. M., Hoffland, E., Van Pelt, J. A., and Van Loon, L. C. 1996. Systemic resistance in Arabidopsis induced by biocontrol bacteria is independent of salicylic acid accumulation and pathogenesis-related gene expression. Plant Cell 8:1225-1237.

Pieterse, C. M. J., Van Wees, S. C. M., Van Pelt, J. A., Knoester, M., Laan, R., Gerrits, H., Weisbeek, P. J., and Van Loon, L. C. 1998. A novel signaling pathway controlling induced systemic resistance in Arabidopsis. Plant Cell 10:1571-1580.

Potter, S., Uknes, S., Lawton, K., Winter, A. M., Chandler, D., DiMaio, J., Novitzky, R., Ward, E., and Ryals, J. 1993. Regulation of a heveinlike gene in Arabidopsis. Mol. Plant-Microbe Interact. 6:680-685.

Roman, G., Lubarsky, B., Kieber, J. J., Rothenberg, M., and Ecker, J. R. 1995. Genetic analysis of ethylene signal transduction in Arabidopsis thaliana: Five novel mutant loci integrated into a stress response pathway. Genetics 139:1393-1409.

Ross, A. F. 1961a. Localized acquired resistance to plant virus infection in hypersensitive hosts. Virology 14:329-339.
Ross, A. F. 1961b. Systemic acquired resistance induced by localized virus infections in plants. Virology 14:340-358.

Ross, A. F., and Williamson, C. E. 1951. Physiologically active emanations from virus-infected plants. Phytopathology 41:431-438.

Schippers, B. 1992. Prospects for management of natural suppresiveness to control soilborne pathogens. Pages 21-34 in: Biological Control of Plant Diseases, Progress and Challenges for the Future. E. C. Tjamos, G. C. Papavizas, and R. J. Cook, eds. Plenum Press, New York.

Schweizer, P., Buchala, A., Silverman, P., Seskar, M., Raskin, I., and Métraux, J.-P. 1997. Jasmonate-inducible genes are activated in rice by pathogen attack without a concomitant increase in endogenous jasmonic acid levels. Plant Physiol. 114:79-88.

Spanu, P., and Boller, T. 1989. Ethylene biosynthesis in tomato plants infected by Phytophthora infestans. J. Plant Physiol. 134:533-537.

Swanson, J., Kearney, B., Dahlbeck, D., and Staskawicz, B. J. 1988. Cloned avirulence gene of Xanthomonas campestris pv. vesicatoria complements spontaneous race-change mutants. Mol. Plant-Microbe Interact. 1:5-9.

Thomashow, L. S., and Weller, D. M. 1996. Current concepts in the use of introduced bacteria for biological disease control: Mechanisms and antifungal metabolites. Pages 187-235 in: Plant-Microbe Interactions. Vol. 1. G. Stacey and N. T. Keen, eds. Chapman \& Hall, New York.

Tsai, F.-Y., Hung, K. T., and Kao, C. H. 1996. An increase in ethylene sensitivity is associated with jasmonate-promoted senescence of detached rice leaves. J. Plant Growth Regul. 15:197-200.

Uknes, S., Mauch-Mani, B., Moyer, M., Potter, S., Williams, S., Dincher, S., Chandler, D., Slusarenko, A., Ward, E., and Ryals, J. 1992. Acquired resistance in Arabidopsis. Plant Cell 4:645-656.

Van Loon, L. C. 1985. Pathogenesis-related proteins. Plant Mol. Biol. 4: 111-116.

Van Loon, L. C. 1997. Induced resistance in plants and the role of pathogenesis-related proteins. Eur. J. Plant Pathol. 103:753-765.

Van Loon, L. C., Bakker, P. A. H. M., and Pieterse, C. M. J. 1998. Systemic resistance induced by rhizosphere bacteria. Annu. Rev. Phytopathol. 36:453-483.

Van Peer, R., Niemann, G. J., and Schippers, B. 1991. Induced resistance and phytoalexin accumulation in biological control of Fusarium wilt of carnation by Pseudomonas sp. strain WCS417r. Phytopathology 81:728-734.

Van Wees, S. C. M., Pieterse, C. M. J., Trijssenaar, A., Van't Westende, Y. A. M., Hartog, F., and Van Loon, L. C. 1997. Differential induction of systemic resistance in Arabidopsis by biocontrol bacteria. Mol. Plant-Microbe Interact. 6:716-724.

Ward, E. R., Uknes, S. J., Williams, S. C., Dincher, S. S., Wiederhold, D. L., Alexander, D. C., Ahl-Goy, P., Métraux, J.-P., and Ryals, J. 1991. Coordinate gene activity in response to agents that induce systemic acquired resistance. Plant Cell 3:1085-1094.

Wei, G., Kloepper, J. W., and Tuzun, S. 1991. Induction of systemic resistance of cucumber to Colletotrichum orbiculare by select strains of plant growth-promoting rhizobacteria. Phytopathology 81:1508-1512.

Weingart, H., and Völksch, B. 1997. Ethylene production by Pseudomonas syringae pathovars in vitro and in planta. Appl. Environ. Microbiol. 63:156-161.

Whalen, M. C., Innes, R. W., Bent, A. F., and Staskawicz, B. J. 1991. Identification of Pseudomonas syringae pathogens of Arabidopsis and a bacterial locus determining avirulence on both Arabidopsis and soybean. Plant Cell 3:49-59. 